\title{
Immunohistochemical Expression of Retinoblastoma Gene Product and p53 Protein in Transitional Cell Carcinoma of the Urinary Bladder and its Relationship to Different Clinicopathological Parameters
}

\author{
Alaa Yahya ${ }^{1}{ }^{1 *}$, Zina A. Rajab Alhamadani ${ }^{2}$, Mohanad Mundher ${ }^{1}$ (D) \\ ${ }^{1}$ Department of Pathology, Al-Kindy College of Medicine, University of Baghdad, Baghdad, Iraq; ${ }^{2}$ Laboratories Teaching, \\ Medical City, Ministry of Health, Baghdad, Iraq
}

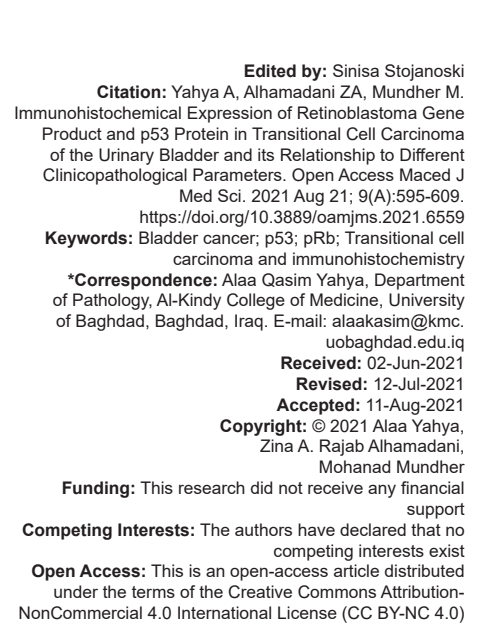

\section{Introduction}

Bladder cancer (BLCA) is one of the most common malignancies that occur at any age and can affect both sexes. However, it affects predominantly middle-aged and elderly men. In males, it ranks as the fourth most common type of cancers after prostatic, lung and colorectal cancers, accounting for $6.6 \%$ of all cases of cancer [1]. In females, it is the ninth commonest cancer, constituting $2.4 \%$ of all cancers [1]. Bladder carcinoma contributes to $3.0 \%$ of all cancerrelated mortality in men and $1.5 \%$ in women. The 5 -year survival rates are higher in men than in women. In adults younger than 30-40 years and adolescents, BLCA tend to be of well-differentiated histologies and behave in an indolent, less aggressive fashion [2]. Racial and regional differences reflect the combined effects of hereditary and environmental factors. They also reflect differences in case reporting [3]. The exact molecular pathways of BLCA formation and progression are not yet fully understood. So that, genetic and molecular factors both may play a crucial role in the progression of BLCA that could be an effective target for treatment of BLCA in the future. An important molecular pathway in the process of carcinogenesis is the inactivation of genes encoding for proteins involved in regulation of cell growth, DNA repair, and apoptosis. Inactivation or 
deletions of these so-called cancer suppressor genes will encourage an unregulated growth and failure to direct cells with damaged DNA towards programmed cell death, resulting in uncontrolled proliferation of genetically unstable clones. Several tumor suppressor genes loci have been closely related to BLCA. These include retinoblastoma $(\mathrm{Rb})$ gene on chromosome $13 q 14$ and p53 on chromosome 17p13 [2], [4].

Progression through cell-cycle is regulated by complex molecular pathway involving cyclins, cyclin-dependent kinases (CDK), and CDK inhibitors (CDKIs) [5]. The Rb and p53 growth suppressor genes play an essential role in the control of the cell cycle [5]. P53-dependent G1-S and G2-M cell-cycle arrest is mediated in part, through p53-mediated activation of the CDKI p21 and suppression of the promoters of cyclins B1 and CDK1, respectively [6]. The Rb pathway is involved in the inhibition of transcription of genes necessary for the G1-S transition [6]. Hypophosphorylated Rb protein binds to and inactivates the transcription factors, notably the E2F1, that is important for the G1-S transition. As the cycle progresses, $\mathrm{pRb}$ becomes hyperphosphorylated and loses its ability to bind to and inactivate E2F1. The phosphorylation of $\mathrm{pRb}$ is done by the cyclin D-CDK4/6 complexes and is inhibited by the CDKI p16 [5].

Abnormalities in the cell-cycle components are common in urinary bladder urothelial carcinomas (BUC) and may be related to the pathogenesis and clinical behavior of these tumors [5]. P53 mutation and/ or protein overexpression was significantly related to tumor grade, stage and the presence or absence of lymph node metastases [5].

The $\mathrm{Rb}$ protein is a major tumor suppressor, controlling cellular processes and responses to oncogenic stimuli, like DNA damage, repeated rapid cells division, as well as inappropriate mitogenic signal [7], [8]. The importance of Rb protein in tumor development was first shown by the results of RB allele being always deleted in $\mathrm{Rb}$ [9]. Altered $\mathrm{pRb}$ protein expression is present in all grades and stages of bladder urothelial carcinoma and is more commonly seen in higher grade and muscle invasive tumors [5]. The immunohistochemical overexpression of $\mathrm{pRb}$ protein has been linked with increased rate of tumor progression and decreased survival [5]. Aberrant expression of p16 and cyclin D1 proteins had been related to urothelial carcinogenesis and tumor recurrence [10], [11], [12]

About ninety $\%$ of urinary bladder malignancies are urothelial cell carcinomas, which are broadly grouped into muscle-invasive bladder carcinoma (MIBC) and non-MIBC (NMIBC) [13]. MIBC usually presents with a poor prognosis, and this represents more than $50 \%$ of mortality account for their disease [14]. On the other hand, patients with NMIBC generally have a variable clinical behavior with potential for progression and significant risk of recurrence [15]. The International Society of Urological Pathology (ISUP) meeting in 2013 declared that there is no ideal marker with respect of urothelial differentiation [16]. However, in recent years, there have been a great effort in biomarkers in the prognosis and prediction of BLCA, such as protein 53 (p53), protein 21 (p21), RB transcriptional corepressor (pRB), and so on [17]. Even more useful is the probability of finding a precise biomarker that could be applied to the routine clinical practice to evaluate the clinical outcome by immunohistochemistry [18].

\section{Aims of the study}

The aim of the study is as follows:

1. To study immunohistochemical expression of $\mathrm{Rb}$ gene through its protein product $(\mathrm{pRb})$ and P53 gene through its protein product in transitional cell carcinoma (TCC) of urinary bladder.

2. To correlate between such expressions and other well-known risk factors and prognostic parameters of the bladder TCC, such as grade, stage, smoking, alcohol drinking, history of urinary tract infection (UTI) or lithiasis, and family history.

\section{Patients, Materials and Methods}

\section{Selection of patients}

In this prospective study, the patients were recruited from the urosurgical department/Surgical Subspecialties Teaching Hospital from November 2020 through April 2021.

Sixty-four patients suspected to have bladder carcinoma were examined endoscopically under general anesthesia by their urosurgeons. Of these, 51 patients had bladder mass, which was either resected (alone or as a part of radical cystectomy) or biopsied, whereas thirteen had no detectable mass. The latter group was not followed further. Of the remaining 51 patients with bladder mass lesion, the biopsy results disclosed in further thirteen patients, cystitis (and its associated mucosal nodularity and edema) without evidence of tumor. This left us with thirty eight, whose biopsy histology confirmed the presence of carcinomas. The carcinomas were transional in 34 patients, adenocarcinoma in two patients, squamous cell carcinoma in one patient, and small cell carcinoma in one patient. Those with non-TCC (four patients) were excluded from further follow-up; the remaining 34 patients were supposed to constitute the core of our study. Regrettably, the histological blocks of two patients were taken by their relatives to get a second consultation opinion regarding the diagnosis; these blocks were never returned back at least during the period of the study. Thus, our study was concentrated 
on 31 patients only. Clinical information regarding name, age, gender, residence, symptomatology, as well as specific questions regarding family history of similar cancer, smoking and drinking habits, history of UTI and renal stones, etc., was obtained either directly from the patient or from the hospital records. The results of physical examination, imaging studies and other relevant particulars were obtained from the case notes of the patients or through direct communication with the respective specialist in charge of the case, and we analyzed our work as follow:

\section{Study group}

In this study, 64 patients were recruited; they were suspected of having urinary bladder carcinoma. The work up included full history and clinical examination. Surgical samples were taken from 51 patients for histopathological evaluations; the samples were either endoscopic cup biopsy, transurethral resection of the tumor, or radical cystectomy. Sections obtained from the forementioned samples were stained with conventional hematoxylineeosine stain. Immunohistochemical staining for P53 and $\mathrm{pRB}$ was then done for the 31 patient samples diagnosed with TCC.

\section{Positive control}

These comprise samples of adenocarcinoma of the lung; positive staining of the tumor cells was considered as a positive control for P53.

Similarly, specimens of small cell carcinoma of the lung were treated with primary antibody of $p R b$; positive staining of the small cell carcinoma cells was considered as a positive control for $\mathrm{pRb}$.

\section{Negative control}

Additional sections from the study group were treated identical to the sections under investigation but with the omission of the primary antibody $(\mathrm{pRb})$ or $\left(\mathrm{P}^{53}\right)$ and were considered as negative controls for each set of slides.

\section{workup \\ Histological and immunohistochemical}

\section{Sample preparation}

Paraffin-embedded tissue blocks of the collected samples as well as the control groups were prepared. Sections were made from each of the paraffin embedded blocks and as follows: paraffin block

Eight, $4 \mu \mathrm{m}$-thick sections were cut from each

- $\quad$ Four sections were subjected for hematoxylin and eosin staining. Ordinary non-charged glass slides were used. This was conducted to evaluate the cases microscopically.

- The other four sections were used for immunohistochemical staining procedures to detect P53 and PRB. In this instance positively charged slides were used.

\section{pRb tumor marker}

Specific reagents

Immunohistochemistry detection kit, Mouse IgG, Bioassay (United States Biological, USA), and antibody ( $\mathrm{pRb}$ tag antibody). The kit contains the followings:

- $\quad$ Anti-Mouse lgG (Biotin).

- DAB, DAB Buffer and DAB Detoxification Reagent

- Normal serum

- $\quad$ Solution A and B

Rb antibody: MBI IH-60030, Human pRb Biotin DNA L.N. 22057095.

General reagents and solutions source

All are listed in Table 1.

Table 1: General reagents and solutions used throughout the study

\begin{tabular}{ll}
\hline General reagents and solutions & Brand \\
\hline Absolute ethanol & BDH (England) \\
Counter stain (hematoxylin and Nuclear Fast Red) & Hopkins and Williams \\
Distilled water & \\
Mounting medium & DPX (BDH, England) \\
Xylene & Merck (Germany) \\
Phosphate buffered saline (PBS) & OXIOD (England) \\
\hline
\end{tabular}

Immunohistochemistry for the detection of transcription factor pRb (Immunohistochemistry Detection Kit, Mouse IgG, BioAssay)

\section{Principle of the test}

A biotinylated, cross-adsorbed, and affinity purified secondary anti-mouse IgG is used to detect primary antibody-antigen complexes adhered to a glass microscope slide, following reaction with an enhanced detection reagent.

Preparation of tissue sections and reagents

1. Paraffin-embedded tissue sections were cut $4 \mu \mathrm{m}$ thick, floated in protein-free water bath, and then placed on Biocare techniques starfrost slides, left at room temperature to dry and then in $55^{\circ} \mathrm{C}$ overnight.

2. Counter stain hematoxylin was prepared by dissolving $10 \mu \mathrm{g}$ hematoxylin in $1000 \mathrm{ml}$ distilled water to which $0.5 \mathrm{ml}$ acetic acid and $1 / 2$ thymol tablets were added. 
3. Citric buffer was prepared by diluting $10 \mathrm{ml}$ of $100 \times$ concentrated citric buffer into distilled water to a final volume of $1000 \mathrm{ml}$.

4. Biotin was prepared by mixing $1.4 \mathrm{ml}$ of $1 \times$ Phosphate buffered saline (PBS), $\mathrm{pH} 7.4$ and $35 \mu \mathrm{l}$ of biotin in a tube.

5. Detection solution was prepared by mixing 35 $\mu \mathrm{l}$ of solution $A$ and $35 \mu$ l of solution $B$ in a tube and incubated at room temperature for $30 \mathrm{~min}$ before use.

6. Fresh development solution was made by mixing $1.6 \mathrm{ml}$ of DAB Buffer and $35 \mu \mathrm{l}$ of DAB in a tube.

7. Normal serum $1 \%$ was prepared by mixing $3.5 \mathrm{ml} 1 \times$ PBS with $35 \mu \mathrm{l}$ of normal serum.

\section{Immunohistochemistry procedure}

The slides were incubated over night at $65^{\circ} \mathrm{C}$ in vertical position for deparaffinization then:

\section{Day 1}

- $\quad$ The slides were soaked in xylene twice, each time for $15 \mathrm{~min}$.

- Dehydration by ethanol alcohol in the following order: 100\% (I), 100\% (II), 95\%, 90\%, 80\%, and $70 \%$ for $5 \mathrm{~min}$ in each solution then in distilled water for $5 \mathrm{~min}$.

- $\quad$ The slides were immersed in $0.3 \% \mathrm{H}_{2} \mathrm{O}_{2}$ (in distilled water) for $30 \mathrm{~min}$ at room temperature.

- $\quad$ The slides were rinsed by distilled water followed by $1 \times$ PBS ( $\mathrm{pH} 7.4)$.

- $\quad$ Antigen retrieval was done by immersing the slides in citric buffer jar followed by placing the latter in a microwave oven set at 720 watt for $10 \mathrm{~min}$.

Note: Four methods were tried for antigen retrieval which are:
A. Microwave oven for $10 \mathrm{~min}$.
B. Autoclave for $2 \mathrm{~min}$.
C. Water bath for $10 \mathrm{~min}$ set at boiling temperature.
D. No retrieval.

The best expression was obtained with the use of microwave oven.

- $\quad$ The tissue sections were circled by a Pap Pen.

- Incubation of the slides with 1\% normal serum was done for $30 \mathrm{~min}$ at room temperature $\left(25^{\circ} \mathrm{C}\right)$.

- Normal serum dropped off and overnight incubation with pRb antibody diluted (1:10) was performed.

Day 2

- $\quad$ The slides were rinsed 3 times with $1 \times$ PBS for $5 \mathrm{~min}$ each. $\bullet$

-

$\bullet$

-
Incubation with anti-mouse IgG (biotin) was done for $30 \mathrm{~min}$ at room temperature (after addition of $20 \mu \mathrm{l}$ of anti IgG on the section). The slides were rinsed 3 times with $1 \times$ PBS for 5 min each.

Incubated with the detection solution for $30 \mathrm{~min}$ at room temperature.

The slides were rinsed 3 times with $1 \times$ PBS for 5 min each.

Incubated with development solution $(20 \mu \mathrm{l})$ for 5-30 min then reaction was stopped by soaking in distilled water.

Hematoxylin stain was used by placing two to three drops (20 $\mu$ l each) on the slide for $1 \mathrm{~min}$ followed by washing slides thoroughly in tab water. Dehydration was done by soaking in graded series of alcohol: $70 \%-80 \%-90 \%-95 \%-100 \%$ (I) $-100 \%$ (II), 3 min each, then Xylene twice for 10 min each.

DPX and cover slips were added and slides were ready for scoring.

\section{Evaluation of Immunohistochemical protein expression}

A biotinylated, cross-adsorbed, and affinity purified secondary anti-mouse $\lg G$ was used to detect primary antibody-antigen complexes adhered to a positively charged glass microscope slide, following reaction with an enhanced detection reagent, proper, and accurate application of kit instructions led to appearance of a brown nuclear precipitate in positive cells on tissue sections.

Readings were done double blindly by two pathologists; IHC was given intensity and percentage scores, based on intensity of positive staining and number of cells staining, respectively. A scale of $0-3$ was used to measure relative intensity with 0 corresponding to no detectable $\mathrm{IHC}$ reaction and 1 equivalent to low, 2 equivalents to moderate, and 3 equivalents to high. Positive cells were counted in ten different fields for each samples and the average of positive cells of the ten fields was determined assigning cases to one of the 4 following categories:

i. Score 1: $1-25 \%$.

ii. Score 2: $26-50 \%$.

iii. Score $3: 51-75 \%$.

iv. Score 4: 76-100\% [19].

For the intensity of staining, an intensity score of $>1$ was assigned as high and a percentage score of $>3$ was categorized as high [19].

\section{P53 tumor marker}

\section{Solutions and Reagents}

a. Primary antibodies: Monoclonal Mouse AntiHuman P53 Protein, 11 ml, Ready-To-Use, 
DAKO, Clone DO-7, Code M7001, LOT 00005848, Dakopatts Corporation, USA.

b. Antibody Diluent with Background Reducing Components, 125ml, Code S0809, LOT 00002288, Dako North America, with a dilution of $1: 25$.

c. Antigen retrieval: Target Retrieval Solution, 500 ml, Code S2368, LOT 00026677, Dako Denmark A/S Produktionsvej 42 DK-2600 Glostrup, phosphate buffer solution, $\mathrm{pH} 6.0$ for P53.

d. Buffer solution: Phosphate buffer for P53.

e. Staining kit: DakoCytomation, Code K0673, sufficient for 150 tissue sections, based on $100 \mathrm{ml}$ per section, which includes: Peroxidase Block, $1 \times 15 \mathrm{ml}, 3 \%$ hydrogen peroxide in water.

1. Biotinylated Link, $1 \times 15 \mathrm{ml}$, biotin labeled affinity isolated goat anti-rabbit and goat antimouse immunoglobulins in PBS, containing stabilizing protein and $0.015 \mathrm{~mol} / \mathrm{L}$ sodium azide.

2. Streptovidin-HRP: $1 \times 15 \mathrm{ml}$, Streptovidin conjugated to horseradish peroxidase in PBS containing stabilizing protein and antimicrobial agents.

3. DAB substrate buffer, $1 \times 18 \mathrm{ml}$, Imidazole$\mathrm{HCL}$ buffer $\mathrm{PH} 7.5$ containing hydrogen peroxide and an anti-microbial agents.

4. DAB chromogen, $1 \times 1 \mathrm{ml}$, 3,3'-diaminobenzidine in chromogen solution.

5. Accessories: Calibrated test tube, plastic Pasteur pipette.

\section{(Technique)}

\section{Immunohistochemical staining protocol}

The Avidin Biotin Complex detection system was used on specimens of five microns thick sections that were cut from the formalin-fixed, paraffin-embedded blocks and placed on positively charged slides.

- Deparaffinization by heating the slides in an oven at $65^{\circ} \mathrm{C}$ for $60 \mathrm{~min}$ followed by two changes of xylene for 10 min each.

- Rehydration done through serial alcohol concentrations of $100 \%, 95 \%, 90 \%, 80 \%$, and $70 \%$, each for $5 \mathrm{~min}$ and then in distilled water for another $5 \mathrm{~min}$.

- Immersion in retrieval (phosphate buffer, $\mathrm{pH} 6.0$ for P53), by heating in the microwave at low heat for 20 min then medium heat for $15 \mathrm{~min}$ then high heat for $10 \mathrm{~min}$.

- $\quad$ Sections were let to cool at room temperature (for $30 \mathrm{~min}$ ).

- $\quad$ Bathing in PBS (for 2-5 min).

- $\quad$ Slides were tapped of excess buffer followed by wiping around the sections by gauze pad. A circle was made around the sections by a PAP pen.
Enough hydrogen peroxide was applied (10 min).

Sections were washed in a phosphate buffer, tapped of excess buffer; the slide was wiped around the sections.

Enough primary antibodies were applied (for $60 \mathrm{~min})$.

The sections were washed and excess fluid was removed by wiping around the sections.

A biotinylated link was applied (30 min).

Sections were washed and wiped around.

Streptavidin-peroxide was applied for (30 min).

Sections were then wash and wiped around.

Substrate-chromogen was then applied for (5-15 min).

Sections where then washed in distilled water Sections were counter stained with Meyer's hematoxylin then rinsed in tap water, mounted with mounting medium, and covered with cover slips examined under light microscope.

\section{Scoring system}

The criterion for positive immunoreactions for P53 is a dark brown nuclear precipitate. Quantification of p53 protein expression was evaluated under light microscopy at low power $\times 40$ and $\times 100(\times 4$, and $\times 10$ objectives respectively an $\times 10$ eye pieces), whereas the counting of positive cells (nuclear staining) was performed at oil emersion $(\times 100)$.

Each sample was scanned for at least ten fields with a high power magnification.

The scoring was done according to [20], at 40 $\times$ objective as follow:

Score (0): Negative, none of the cells are positive for the marker.

Score $(+1)$ : Mild or weak staining; $5-10 \%$ of the cells are positive for the marker.

Score $(+2)$ : Moderate staining; $<25 \%$ of the cells are positive for the marker.

Score $(+3)$ : Strong staining; $25-50 \%$ of the cells are positive for the marker.

Score (+4): Highly strong staining, over $50 \%$ of tumor cells are stained positive.

\section{Qualitative assessment}

Faint staining pattern, whether cytoplasmic or nuclear, that could only be detected by using higher magnification (objective 40). Strong staining pattern is easily seen by low magnification (objective 4).

\section{Photography}

Pictures were taken by adjusting a digital camera lens on the eye piece of the microscope (oil immersion, $\times 1000$, and $\times 400$ ). Sony Cyber Shot 
digital camera with 8.1 mega pixels was used and the files were saved in joint photographic experts group format.

\section{Statistical analysis}

Statistical analysis was performed with SPSS 16 for windows evaluation version and the Microsoft Office Excel (2007). Univariate data were summarized using standard descriptive statistics, tabulation of the categorical variables and histograms of the numerical variables. Correlations between the categorical variables were assessed through cross tabulations and Chi-squares. In all statistical analyses, $p<0.05$ was considered to be significant.

\section{Results}

\section{Statistical results}

Clinicopathological data

Age distribution

The age range of the studied patients was 28-85 years old with the mean age 60.2 years and median age of 67 years. The majority of the studied patients were in the age group of $61-70$ years (13), $(40.6 \%)$, whereas the minority was in the age groups of $21-30$ years and $31-40$ years (1), (3.1\%). The rest of the patients were distributed in the age groups below as shown in Table 2.

Table 2: Age distribution of the 32 patients with TCC

\begin{tabular}{lccc}
\hline Age groups (years) & Frequency & Percent & Cumulative Percent \\
\hline $21-30$ & 1 & 3.1 & 3.1 \\
$31-40$ & 1 & 3.1 & 6.2 \\
$41-50$ & 4 & 12.5 & 18.8 \\
$51-60$ & 6 & 18.8 & 37.5 \\
$61-70$ & 13 & 40.6 & 78.1 \\
$71-80$ & 5 & 15.6 & 93.8 \\
$81-90$ & 2 & 6.2 & 100.0 \\
Total & 32 & 100.0 & \\
\hline
\end{tabular}

\section{Gender distribution}

In this study, 22 patients $(68.8 \%)$ were males and tten patients $(31.2 \%)$ were females as shown in Table 3.

Table 3: Gender distribution in 32 patients with TCC

\begin{tabular}{llll}
\hline Gender & Frequency & Percent & Cumulative Percent \\
\hline Male & 22 & 68.8 & 68.8 \\
Female & 10 & 31.2 & 100.0 \\
Total & 32 & 100.0 & \\
\hline
\end{tabular}

\section{Smoking}

Of the total 32 patients, $19(59 \%)$ were smokers, the rest were nonsmokers as shown in Table 4.
Table 4: Smoking habit in 32 patients with transitional cell carcinoma of the bladder

\begin{tabular}{llll}
\hline Smoking history & Frequency & Percent & Cumulative Percent \\
\hline Non smokers & 13 & 40.6 & 40.6 \\
Smokers & 19 & 59.4 & 100.0 \\
Total & 32 & 100.0 & \\
\hline
\end{tabular}

\section{Amount of smoking}

The number of the cigarettes smoked of those 19 smokers differed widely; they ranged from 1 to 5 cigarettes/day up to 61 to 80 cigarettes/day. The full data regarding smoking habit are tabulated in Table 5.

Table 5: Amount of cigarettes smoking in 32 patients with transitional cell carcinoma of the bladder

\begin{tabular}{llll}
\hline Amount of smoking & Frequency & Percent & Cumulative Percent \\
\hline Not smoker & 13 & 40.6 & 40.6 \\
$1-5$ cigarettes & 1 & 3.1 & 43.8 \\
$6-10$ cigarettes & 3 & 9.4 & 53.1 \\
$11-20$ cigarettes & 7 & 21.9 & 75.0 \\
$21-30$ cigarettes & 1 & 3.1 & 78.1 \\
$31-40$ cigarettes & 4 & 12.5 & 90.6 \\
$41-60$ cigarettes & 2 & 6.2 & 96.9 \\
$61-80$ cigarettes & 1 & 3.1 & 100.0 \\
Total & 32 & 100.0 & \\
\hline
\end{tabular}

\section{Duration of smoking}

The duration of smoking in those 19 smoking patients also varied widely and ranged from (6 years to 58 years). Full information regarding duration of smoking is shown in Table 6.

Table 6: Duration of smoking of the 19 smokers with transitional cell carcinoma of the bladder

\begin{tabular}{llll}
\hline Duration of smoking (years) & Frequency & Percent & Cumulative Percent \\
\hline $0-10$ & 1 & 5.26 & 5.26 \\
$11-20$ & 5 & 26.31 & 31.57 \\
$21-30$ & 4 & 21.05 & 52.62 \\
$31-40$ & 7 & 36.84 & 89.46 \\
$41-50$ & 1 & 5.26 & 94.72 \\
$51-60$ & 1 & 5.26 & 100.0 \\
Total & 19 & 100.0 & \\
\hline
\end{tabular}

\section{Association with UTI}

History of (UTI) in those 32 patients with TCC revealed that $18(56.2 \%)$ patients have had no history of (UTI), while $14(43.8 \%)$ patients have had such a history as shown in Table 7.

Table 7: Frequency distribution of the 32 patients with and without a history of UTI

\begin{tabular}{llll}
\hline History of UTI & Frequency & Percent & Cumulative Percent \\
\hline No UTI & 18 & 56.2 & 56.2 \\
UTI & 14 & 43.8 & 100.0 \\
Total & 32 & 100.0 & \\
\hline
\end{tabular}

Family history of urothelial carcinoma

Of the 32 patients with TCC of the urinary bladder only three patients $(9.4 \%)$ had a positive family history of TCC; this is shown in Table 8.

Table 8: Frequency of patients with a family history of TCC of urinary bladder

\begin{tabular}{llll}
\hline Family history of blabber cancer & Frequency & Percent & Cumulative Percent \\
\hline Negative for family history & 29 & 90.6 & 90.6 \\
Positive for family history & 3 & 9.4 & 100.0 \\
Total & 32 & 100.0 & \\
\hline
\end{tabular}


Association with urinary lithiasis

Of the 32 patients with TCC, five patients $(15.6 \%)$ have had bladder stones; this is shown in Table 9.

Table 9: Relative frequency of those with TCC of the bladder with a history of bladder stone

\begin{tabular}{llll}
\hline History of lithiasis & Frequency & Percent & Cumulative Percent \\
\hline History of stone & 27 & 84.4 & 84.4 \\
No history of stone & 5 & 15.6 & 100.0 \\
Total & 32 & 100.0 & \\
\hline
\end{tabular}

History of alcohol intake

Only four patients out of the total $(12.5 \%)$ confessed of drinking habits. This is shown in Table 10.

Table 10: frequency of patients with a positive history of alcohol intake among the 32 patients with TCC

\begin{tabular}{llll}
\hline History of alcohol drinking & Frequency & Percent & Cumulative Percent \\
\hline Not drinker & 28 & 87.5 & 87.5 \\
drinker & 4 & 12.5 & 100.0 \\
Total & 32 & 100.0 & \\
\hline
\end{tabular}

\section{Tumor recurrence}

Of the total 32 patients with TCC of the urinary bladder 17 patients have had a previous documented history of similar tumors, that is, during this study they were in reality cases with a recurrent disease. This is shown in Table 11.

Table 11: Relative frequency of recurrent TCC

\begin{tabular}{llll}
\hline History of TCC & No. of patients & Percent & Cumulative Percent \\
\hline Primary cases & 15 & 46.9 & 46.9 \\
Recurrent cases & 17 & 53.1 & 100.0 \\
Total & 32 & 100.0 & \\
\hline
\end{tabular}

\section{Tumor grade}

Histopathological assessment of the tumor grade in the 32 patients with TCC revealed that (14) patients had low-grade tumors whereas the remaining (18) had high-grade ones (Figures 1 and 2). This is show in Table 12.

Table 12: Relative frequency of TCC cases with respect to the grade

\begin{tabular}{llll}
\hline Tumor grade & Frequency & Percent & Cumulative Percent \\
\hline Low grade & 14 & 43.8 & 43.8 \\
High grade & 18 & 56.2 & 100.0 \\
Total & 32 & 100.0 & \\
\hline
\end{tabular}

\section{Tumor stage}

Staging of the studied tumors according to TNM staging system revealed that the majority of the cases had T1 a tumors (18 patients; $56.2 \%$ ) followed by T1b tumors (6 patients; 18.8\%). This is shown in detail in Table 13. It should be mentioned that only one patient (T4a) of the total showed lymph node enlargement through imaging techniques (N1), and that none of
Table 13: Relative frequency of TCC according the TNM staging

\begin{tabular}{llll}
\hline Tumor stage & Frequency & Percent & Cumulative Percent \\
\hline Tis & 1 & 3.1 & 3.1 \\
T1a & 18 & 56.2 & 59.4 \\
T1b & 6 & 18.8 & 78.1 \\
T2a & 1 & 3.1 & 81.2 \\
T3a & 2 & 6.2 & 87.5 \\
T3b & 2 & 6.2 & 93.8 \\
T4aN0Mx & 1 & 3.1 & 96.9 \\
T4aN1Mx & 1 & 3.1 & 100.0 \\
Total & 32 & 100.0 & \\
\hline
\end{tabular}

the cases had distant metastases documented by the imaging studies (M0).

\section{Correlations between different clinicopathological data}

In this study, a correlation is attempted between tumor grade and some clinicopathological data such as age, gender, smoking habit, history of UTI, history of renal stone, family history of TCC, recurrence of the tumor, and tumor stage.

\section{Correlation between tumor grade and age}

In this study, high-grade tumors were more commonly encountered than low-grade tumors (18 patients vs. 14). The highest incidence of low-grade tumors was in the age group 61-70 years (6 patients of the 32 ); and the highest incidence of high-grade tumors was also in this very age group (7 patients out of the 32). The frequency of low- and high-grade urothelial carcinomas with respect to the various age groups is detailed in Table 14. Hence, the correlation between tumor grade and patients age was not significant since $p=0.101$.

Table 14: Correlation between age groups and tumor grade

\begin{tabular}{|c|c|c|c|}
\hline Tumor grade- Age Cross tabulation & Tumor grad & & \\
\hline Age (years) & Low grade & High grade & Total \\
\hline $21-30$ & 1 & 0 & 1 \\
\hline $31-40$ & 0 & 1 & 1 \\
\hline $41-50$ & 1 & 3 & 4 \\
\hline $51-60$ & 3 & 3 & 6 \\
\hline $61-70$ & 6 & 7 & 13 \\
\hline $71-80$ & 3 & 2 & 5 \\
\hline $81-90$ & 0 & 2 & 2 \\
\hline Total & 14 & 18 & 32 \\
\hline
\end{tabular}

\section{gender \\ Correlation between tumor grade and}

This study comprises 22 males and ten females. Ten out of the 22 males had low grade TCC $(45.5 \%)$. On the other hand, only four out of the ten females had low grade TCC (40\%). This is detailed in Table 15. Such correlations, however, were not statically significant. $(p=0.288)$.

Table 15: Correlation between tumor grade and gender

\begin{tabular}{lllll}
\hline Gender-Tumor grade Cross tabulation & & Tumor grade & & \\
\cline { 1 - 1 } \cline { 5 - 6 } Gender & & Low grade & High grade & Total \\
\hline Male & & 10 & 12 & 22 \\
Female & 4 & 6 & 10 \\
Total & & 14 & 18 & 32 \\
\hline$p=0.288$ (Not significant) & &
\end{tabular}




\section{smoking}

\section{Correlation between tumor grade and}

Of the 32 urothelial carcinomas studied, smokers outnumbered nonsmokers (59.3\% vs. $40.6 \%)$. In addition, smokers displayed slightly more relative frequency of high-grade tumors than nonsmokers $(34.3 \%$ vs. $21.8 \%)$ out of the 32 patients. This is detailed in Table 16. However, statistically the above associations were not significant.

Table 16: Correlation between smoking habit and tumor grade

\begin{tabular}{lllll}
\hline Smoking-Tumor grade Cross tabulation & & Tumor grade & & \\
\cline { 1 - 1 } \cline { 5 - 6 } Smoking & & Low grade & High grade & Total \\
\hline Non smoker & 6 & 7 & 13 \\
Smoker & 8 & 11 & 19 \\
Total & 14 & 18 & 32 \\
\hline $\mathrm{p}=0.275$ (Not significant). & & &
\end{tabular}

\section{Correlation between tumor grade and UTI}

In this study, the number of patients with urothelial carcinoma but no history of UTI outnumbered those with UTI (18 vs. 14). However, the relative frequency of high-grade tumors is higher in those with a history of UTI than those without such history, (31.2\% vs. $25 \%$ ). These associations are detailed in Table 17. There was no significant difference since the $p=0.093$.

Table 17: Correlation between tumor grade and history of UTI

\begin{tabular}{lllll}
\cline { 1 - 3 } History of UTI- Tumor grade Cross tabulation & & Tumor grade & & \\
\cline { 1 - 2 } \cline { 3 - 5 } History of UTI & Low grade & High grade & Total \\
\hline No UTI & 10 & 8 & 18 \\
Has UTI & 4 & 10 & 14 \\
Total & 14 & 18 & 32 \\
\hline$p=0.093$ (Not significant) & &
\end{tabular}

\section{Correlation between tumor grade and family history}

Eleven patients out of 29 who had no family history for TCC with low grade and 18 with high grade TCC, while three patients who had positive family history all with low grade TCC as shown in Table 18. There no significant correlation between the two variables since $p=0.073$.

Table 18: Correlation between family history and tumor grade

\begin{tabular}{lllll}
\cline { 1 - 3 } Family history-Tumor grade Cross tabulation & & Tumor grade & & \\
\cline { 1 - 1 } \cline { 5 - 5 } Family history & & Low grade & High grade & Total \\
\cline { 1 - 4 } Negative for family history & 11 & 18 & 29 \\
positive for family history & 3 & 0 & 3 \\
Total & 14 & 18 & 32 \\
\hline$p=0.073$ (Not significant). & & &
\end{tabular}

\section{Correlation between tumor grade and history of bladder stone}

Those with a history of bladder stones displayed a higher relative frequency of high-grade tumors than those without $(9.3 \%$ vs. $6.25 \%)$ out of the 32 patients. The various associations are detailed in Table 19. There was no significant association between tumor grade and bladder stone since $p=0.369$.
Table 19: Correlation between history of bladder stones and tumor grade.

\begin{tabular}{lllll}
\hline History of bladder stone-Tumor grade Cross tabulation & & \multicolumn{3}{l}{ Tumor grade } \\
\cline { 1 - 1 } History of bladder stone & Low grade & High grade & Total \\
\hline No stone & 12 & 15 & 27 \\
Has a stone & 2 & 3 & 5 \\
Total & 14 & 18 & 32 \\
\hline$p=0.36$ (Not significant). & & &
\end{tabular}

\section{Correlation between tumor grade and recurrence of tumor}

Those patients with recurrent tumors displayed slightly higher relative frequency of high-grade carcinomas than those patients with primary tumors $(55.5 \%$ vs. $44.5 \%)$ out of 18 patients with high grade tumor. The correlation is not, however, statistically significant $(p=0.265)$. The relationship between these two parameters is detailed in Table 20.

Table 20: Correlation between tumor grade and recurrence of malignancy

\begin{tabular}{lllll}
\hline Primary or recurrent cases-Tumor grade Cross tabulation & & \multicolumn{4}{l}{ Tumor grade } \\
\cline { 1 - 1 } \cline { 5 - 6 } Primary or recurrent cases & & Low grade & High grade & Total \\
\hline Primary cases & 7 & $8(44.5 \%)$ & 15 \\
Recurrent cases & 7 & $10(55.5 \%)$ & 17 \\
Total & 14 & $18(100 \%)$ & 32 \\
\hline$p=0.265$ (not significant). & &
\end{tabular}

\section{Correlation between tumor grade and}

stage

All the (14) patients with low-grade tumors, in this study, show superficial invasion, that is, limited to mucosa/submucosa (T1a or T1b); however, seven of the eighteen patients $(38.9 \%)$ with high-grade tumors presented in advanced stages, that is, T2 or more. This finding was found to be statistically significant with $p=0.003$. The relationship between tumor grade and stage is detailed in Table 21.

Table 21: Correlation between tumor grade and stage

\begin{tabular}{|c|c|c|c|c|c|c|c|c|c|}
\hline \multirow{2}{*}{$\begin{array}{l}\text { Tumor grade-tumor } \\
\text { stage cross tabulation } \\
\text { Tumor grade }\end{array}$} & \multicolumn{9}{|c|}{ Tumor stage } \\
\hline & TIS & T1a & T1b & T2a & T3a & T3b & T4aNOMx & T4aN1Mx & Total \\
\hline Low grade & 1 & 10 & 3 & 0 & 0 & 0 & 0 & 0 & 14 \\
\hline High grade & 0 & 8 & 3 & 1 & 2 & 2 & 1 & 1 & 18 \\
\hline Total & 1 & 18 & 6 & 1 & 2 & 2 & 1 & 1 & 32 \\
\hline
\end{tabular}

\section{Immunohistochemical scores}

\section{PRb scores}

Two patients out of the total 32 showed negative $\mathrm{pRb}$ intensity and percentage scores. The remaining 30 patients showed variable intensity and percentage scores (Figure 3).

\section{Intensity scores}

Half of the patients studied displayed low intensity scores, whereas about one-third revealed moderate intensity. Rare carcinomas showed high intensity. These findings are detailed in Table 22. 
Table 22: Frequency distribution of various PRb intensity scores

\begin{tabular}{llll}
\hline PRb intensity score & Frequency & Percent & Cumulative Percent \\
\hline Negative staining & 2 & 6.2 & 6.2 \\
Low intensity & 16 & 50.0 & 56.2 \\
Moderate intensity & 11 & 34.4 & 90.6 \\
High intensity & 3 & 9.4 & 100.0 \\
Total & 32 & 100.0 & \\
\hline
\end{tabular}

Percentage scores

The results of the percentage scores parallel those of the intensity in that almost half of the patients revealed +1 score, about one-third revealed +2 score. +3 score was rarely reported. These results are detailed in Table 23.

Table 23: Frequency distribution of various PRb percentage scores of the $\mathbf{3 2}$ urothelial carcinomas

\begin{tabular}{llll}
\hline PRb percentage score & Frequency & Percent & Cumulative Percent \\
\hline Negative 0\% & 2 & 6.2 & 6.2 \\
$1-25 \%(+1)$ & 15 & 46.9 & 53.1 \\
$26-50 \%(+2)$ & 11 & 34.4 & 87.5 \\
$51-75 \%(+3)$ & 4 & 12.5 & 100.0 \\
Total & 32 & 100.0 & \\
\hline
\end{tabular}

\section{P53 scores}

Positive expression of $p^{53}$ protein by immunohistochemistry was detected as brownish precipitate in the nucleus of the tumor cells and that was used in scoring of $p^{53}$ expression.

Six patients $(18.8 \%)$ revealed negative staining so negative for both intensity and percentage scores (Figure 4).

\section{Intensity score}

The intensity of expression of P53 varied from weak or mild up to very strong, with one-third of the tumors $(34.4 \%)$ showing moderate intensity. This is detailed in Table 24.

Table 24: Distribution of $\mathrm{P}^{53}$ intensity score

\begin{tabular}{lllll}
\hline $\mathrm{P}^{53}$ intensity score & Frequency & Percent & Valid percent & Cumulative percent \\
\hline Negative intensity & 6 & 18.8 & 18.8 & 18.8 \\
Weak or mild intensity & 6 & 18.8 & 18.8 & 37.5 \\
Moderate intensity & 11 & 34.4 & 34.4 & 71.9 \\
Strong intensity & 6 & 18.8 & 18.8 & 90.6 \\
Highly strong intensity & 3 & 9.4 & 9.4 & 100.0 \\
Total & 32 & 100.0 & 100.0 & \\
\hline
\end{tabular}

\section{Percentage score}

The percentage scores of the 32 cases studied ranged from negative for staining up to +3 . About onethird of the cases $(31.2 \%)$ showed a +1 score followed by one-fifth of the cases $(21.9 \%)$ showing +2 score. This is detailed in Table 25.

Table 25: Frequency distribution of $\mathrm{p}^{53}$ percentage score

\begin{tabular}{llll}
\hline $\mathrm{P}^{53}$ percentage score & Frequency & Percent & Cumulative Percent \\
\hline Negative for staining & 6 & 18.8 & 18.8 \\
$5-10 \%$ of tumor cells positive for staining $(+1)$ & 10 & 31.2 & 50.0 \\
$<25 \%$ of tumor cells positive for staining $(+2)$ & 7 & 21.9 & 71.9 \\
25-50\% of tumor cells positive for staining $(+3)$ & 6 & 18.8 & 90.6 \\
Over 50\% of tumor cells positive for staining $(+4)$ & 3 & 9.4 & 100.0 \\
Total & 32 & 100.0 \\
\hline
\end{tabular}

grade

$$
\text { Correlations between } p R b \text { scores and tumor }
$$

$\mathrm{pRb}$ intensity score and tumor grade

The difference between low grade and high grade tumors regarding $\mathrm{pRb}$ intensity score was statistically not significant $p=0.094$ as shown in Table 26.

Table 26: Correlation between pRb intensity score and tumor grade

\begin{tabular}{|c|c|c|c|}
\hline pRb intensity score-Tumor grade Cross tabulation & Tumor grad & & \\
\hline pRb intensity score & Low grade & High grade & Total \\
\hline Negative staining & 2 & 0 & 2 \\
\hline Low intensity & 7 & 9 & 16 \\
\hline Moderate intensity & 4 & 7 & 11 \\
\hline High intensity & 1 & 2 & 3 \\
\hline Total & 14 & 18 & 32 \\
\hline
\end{tabular}

$p=0.094$ (not significant).

$\mathrm{PRb}$ percentage score and tumor grade

The difference between low grade and high grade tumors regarding $\mathrm{pRb}$ percentage score was found to be statistically significant $(p=0.026)$ as shown in Table 27.

Table 27: Correlation between pRb percentage score and tumor grade

\begin{tabular}{|c|c|c|c|}
\hline pRb percentage score-Tumor grade Cross tabulation & Tumor gra & & \\
\hline pRb percentage score & Low grade & High grade & Total \\
\hline Negative $0 \%$ & 2 & 0 & 2 \\
\hline $1-25 \%(+1)$ & 8 & 7 & 15 \\
\hline $26-50 \%(+2)$ & 3 & 8 & 11 \\
\hline $51-75 \%(+3)$ & 1 & 3 & 4 \\
\hline Total & 14 & 18 & 32 \\
\hline
\end{tabular}

\section{Correlations between p53 scores and tumor}

grade

Between p53 intensity score and tumor grade

The difference between low grade and high grad regarding $\mathrm{p}^{53}$ intensity score was significant $\mathrm{p}=0.022$ as shown in Table 28.

Table 28: Correlation between $\mathrm{p}^{53}$ intensity score and tumor grade

\begin{tabular}{|c|c|c|c|}
\hline $\mathrm{P}^{53}$ intensity score-Tumor grade Cross tabulation & Tumor grad & & \\
\hline $\mathrm{p}^{53}$ intensity score & Low grade & High grade & Total \\
\hline Negative staining & 4 & 2 & 6 \\
\hline Weak or mild staining & 3 & 3 & 6 \\
\hline Moderate staining & 5 & 6 & 11 \\
\hline Strong staining & 2 & 4 & 6 \\
\hline Highly strong staining & 0 & 3 & 3 \\
\hline Total & 14 & 18 & 32 \\
\hline
\end{tabular}

Between $\mathrm{p}^{53}$ percentage score and tumor grade

The difference between low grade and high grade urothelial carcinomas regarding $p^{53}$ percentage scores was statistically significant $(p=0.049)$ as shown in Table 29. 
Table 29: Correlation between $\mathrm{p}^{53}$ percentage score and tumor grade

\begin{tabular}{lllll}
\hline $\mathrm{P}^{53}$ percentage score-Tumor grade Cross tabulation & & \multicolumn{3}{l}{ Tumor grade } \\
\cline { 1 - 2 } \cline { 5 - 5 } $\mathrm{P}^{53}$ percentage score & & Low grade & High grade & Total \\
\hline Negative for staining & 4 & 2 & 6 \\
$5-10 \%$ of tumor cells positive for staining $(+1)$ & 4 & 6 & 10 \\
$11-25 \%$ of tumor cells positive for staining $(+2)$ & 3 & 4 & 7 \\
$26-50 \%$ of tumor cells positive for staining $(+3)$ & 3 & 3 & 6 \\
Over $50 \%$ of tumor cells positive for staining $(+4)$ & 0 & 3 & 3 \\
Total & 14 & 18 & 32 \\
\hline $\mathrm{p}=0.04$ (significant). & & &
\end{tabular}

Total

Correlation between $p R b$ scores and tumor

stage

Between $\mathrm{pRb}$ intensity score and tumor stage

The difference between different tumor stages regarding $\mathrm{pRb}$ intensity scores was statistically significant $(p=0.044)$ as shown in Table 30.

Table 30: Correlation between pRb intensity score and tumor stage

\begin{tabular}{|c|c|c|c|c|c|c|c|c|c|}
\hline \multirow{2}{*}{$\begin{array}{l}\text { pRb intensity score- } \\
\text { Tumor stage Cross } \\
\text { tabulation } \\
\text { Prb intensity score }\end{array}$} & \multicolumn{9}{|c|}{ Tumor stage } \\
\hline & CIS & T1a & T1b & T2a & T3a & T3b & T4aNOMx & T4aN1Mx & Total \\
\hline Negative staining & 0 & 2 & 0 & 0 & 0 & 0 & 0 & 0 & 2 \\
\hline Low intensity & 0 & 8 & 4 & 1 & 1 & 1 & 1 & 0 & 16 \\
\hline Moderate intensity & 0 & 6 & 2 & 0 & 1 & 1 & 0 & 1 & 11 \\
\hline High intensity & 1 & 2 & 0 & 0 & 0 & 0 & 0 & 0 & 3 \\
\hline Total & 1 & 18 & 6 & 1 & 2 & 2 & 1 & 1 & 32 \\
\hline
\end{tabular}

Between $\mathrm{pRb}$ percentage score and tumor stage

The difference between different tumor stages regarding $\mathrm{pRb}$ percentage scores was found to be statistically significant $(p=0.042)$ as shown in Table 31 .

Table 31: Correlation between $\mathrm{pRb}$ percentage score and tumor grade

\begin{tabular}{|c|c|c|c|c|c|c|c|c|c|}
\hline \multirow{2}{*}{$\begin{array}{l}\text { PRb percentage } \\
\text { score- Tumor stage } \\
\text { Cross tabulation } \\
\text { pRb percentage score }\end{array}$} & \multicolumn{9}{|c|}{ Tumor stage } \\
\hline & $\mathrm{CIS}$ & T1a & T1b & $\mathrm{T} 2 \mathrm{a}$ & T3a & T3b & T4aNOMx & T4aN1Mx & Total \\
\hline Negative $0 \%$ & 0 & 2 & 0 & 0 & 0 & 0 & 0 & 0 & 2 \\
\hline $1-25 \%(+1)$ & 0 & 9 & 3 & 0 & 1 & 1 & 1 & 0 & 15 \\
\hline $26-50 \%(+2)$ & 0 & 4 & 3 & 1 & 1 & 1 & 0 & 1 & 11 \\
\hline $51-75 \%(+3)$ & 1 & 3 & 0 & 0 & 0 & 0 & 0 & 0 & 4 \\
\hline Total & 1 & 18 & 6 & 1 & 2 & 2 & 1 & 1 & 32 \\
\hline
\end{tabular}

stage

\section{Correlations between $p^{53}$ scores and tumor}

Between $\mathrm{p}^{53}$ intensity score and tumor stage

The difference between different tumor stages regarding $p^{53}$ intensity scores was significant $(p=0.018)$ as shown in Table 32.

Table 32: Correlation between $\mathrm{p}^{53}$ intensity score and tumor stage

\begin{tabular}{|c|c|c|c|c|c|c|c|c|c|}
\hline \multirow{2}{*}{$\begin{array}{l}\mathrm{P}^{53} \text { intensity score- } \\
\text { Tumor stage Cross } \\
\text { tabulation } \\
\mathrm{P}^{53} \text { intensity score }\end{array}$} & \multicolumn{9}{|c|}{ Tumor stage } \\
\hline & $\mathrm{CIS}$ & T1a & T1b & T2a & T3a & T3b & T4aNOMx & T4aN1Mx & Total \\
\hline Negative staining & 1 & 3 & 0 & 0 & 0 & 1 & 1 & 0 & 6 \\
\hline Weak or mild staining & 0 & 3 & 2 & 0 & 0 & 0 & 0 & 1 & 6 \\
\hline Moderate staining & 0 & 4 & 4 & 1 & 1 & 1 & 0 & 0 & 11 \\
\hline Strong staining & 0 & 6 & 0 & 0 & 0 & 0 & 0 & 0 & 6 \\
\hline Highly strong staining & 0 & 2 & 0 & 0 & 1 & 0 & 0 & 0 & 3 \\
\hline Total & 1 & 18 & 6 & 1 & 2 & 2 & 1 & 1 & 32 \\
\hline
\end{tabular}

Between $\mathrm{p}^{53}$ percentage score and tumor stage

The differences between different tumor stages regarding $p^{53}$ percentage score was statistically significant $(p=0.019)$ as shown in Table 33.

Table 33: Correlation between $\mathrm{p}^{53}$ percentage score and tumor stage

\begin{tabular}{|c|c|c|c|c|c|c|c|c|c|}
\hline & Tum & r stage & & & & & & & \\
\hline $\mathrm{P}^{53}$ percentage score & CIS & T1a & $\mathrm{T} 1 \mathrm{~b}$ & T2a & T3a & T3b & T4aNOMx & T4aN1Mx & Total \\
\hline Negative for staining & 1 & 3 & 0 & 0 & 0 & 1 & 1 & 0 & 6 \\
\hline $\begin{array}{l}5-10 \% \text { of tumor cells } \\
\text { positive for staining }(+1)\end{array}$ & 0 & 5 & 3 & 0 & 1 & 0 & 0 & 1 & 10 \\
\hline $\begin{array}{l}<25 \% \text { of tumor cells } \\
\text { positive for staining }(+2)\end{array}$ & 0 & 3 & 2 & 1 & 0 & 1 & 0 & 0 & 7 \\
\hline $\begin{array}{l}25-50 \% \text { of tumor cells } \\
\text { positive for staining }(+3)\end{array}$ & 0 & 5 & 1 & 0 & 0 & 0 & 0 & 0 & 6 \\
\hline $\begin{array}{l}\text { Over } 50 \% \text { of tumor cells } \\
\text { positive for staining }(+4)\end{array}$ & 0 & 2 & 0 & 0 & 1 & 0 & 0 & 0 & 3 \\
\hline Total & 1 & 18 & 6 & 1 & 2 & 2 & 1 & 1 & 32 \\
\hline
\end{tabular}

Correlations between $p R b$ intensity and percentage scores

The correlation between the percentage and intensity scores of $\mathrm{pRb}$ staining shows significant statistical difference since $(p<0.0001)$ as shown in Table 34.

Table 34: Correlation between pRb percentage and intensity scores

\begin{tabular}{|c|c|c|c|c|c|}
\hline \multirow{2}{*}{$\begin{array}{l}\text { pRb percentage score- } \mathrm{pRb} \\
\text { intensity score Cross tabulation } \\
\mathrm{pRb} \text { percentage score }\end{array}$} & \multicolumn{5}{|c|}{ pRb intensity score } \\
\hline & $\begin{array}{l}\text { Negative } \\
\text { staining }\end{array}$ & $\begin{array}{l}\text { Low } \\
\text { intensity }\end{array}$ & $\begin{array}{l}\text { Moderate } \\
\text { intensity }\end{array}$ & $\begin{array}{l}\text { High } \\
\text { intensity }\end{array}$ & Total \\
\hline Negative $0 \%$ & 2 & 0 & 0 & 0 & 2 \\
\hline $1-25 \%(+1)$ & 0 & 13 & 2 & 0 & 15 \\
\hline $26-50 \%(+2)$ & 0 & 3 & 7 & 1 & 11 \\
\hline $51-75 \%(+3)$ & 0 & 0 & 2 & 2 & 4 \\
\hline Total & 2 & 16 & 11 & 3 & 32 \\
\hline
\end{tabular}

\section{Correlation between $p^{53}$ intensity and} percentage scores

The correlation between the percentage and intensity of $p^{53}$ scores shows significant statistical differences $(p<0.0001)$ as shown in Table 35 .

Table 35: Correlation between $\mathrm{p}^{53}$ intensity and percentage scores

\begin{tabular}{|c|c|c|c|c|c|c|}
\hline \multirow{2}{*}{$\begin{array}{l}P^{53} \text { percentage score- } \mathrm{p}^{53} \\
\text { intensity score Cross tabulation } \\
\mathrm{P}^{53} \text { percentage score }\end{array}$} & \multicolumn{6}{|c|}{ p53 intensity score } \\
\hline & $\begin{array}{l}\text { Negative } \\
\text { staining }\end{array}$ & $\begin{array}{l}\text { Weak } \\
\text { or mild } \\
\text { staining }\end{array}$ & $\begin{array}{l}\text { Moderate } \\
\text { staining }\end{array}$ & $\begin{array}{l}\text { Strong } \\
\text { staining }\end{array}$ & $\begin{array}{l}\text { Highly } \\
\text { strong } \\
\text { staining }\end{array}$ & Total \\
\hline Negative for staining & 6 & 0 & 0 & 0 & 0 & 6 \\
\hline $\begin{array}{l}5-10 \% \text { of tumor cells positive } \\
\text { for staining }(+1)\end{array}$ & 0 & 5 & 5 & 0 & 0 & 10 \\
\hline $\begin{array}{l}<25 \% \text { of tumor cells positive for } \\
\text { staining }(+2)\end{array}$ & 0 & 1 & 5 & 1 & 0 & 7 \\
\hline $\begin{array}{l}25-50 \% \text { of tumor cells positive } \\
\text { for staining }(+3)\end{array}$ & 0 & 0 & 1 & 5 & 0 & 6 \\
\hline $\begin{array}{l}\text { Over } 50 \% \text { of tumor cells } \\
\text { positive for staining }(+4)\end{array}$ & 0 & 0 & 0 & 0 & 3 & 3 \\
\hline Total & 6 & 6 & 11 & 6 & 3 & 32 \\
\hline
\end{tabular}




\section{Discussion}

There is a progressive worldwide increase in the incidence and death rates from malignancy over the world including urinary bladder carcinoma which is regarded as one of the commonest ten cancers in Iraq [21]. BLCA is a worldwide problem, and the second most common malignancy of the genitourinary system [22]. Ninety percent of BLCAs are superficial in nature and urothelial TCC accounts for approximately $90 \%$ of them [23]. The molecular phenotyping has shown a new dimension to the characterization of the

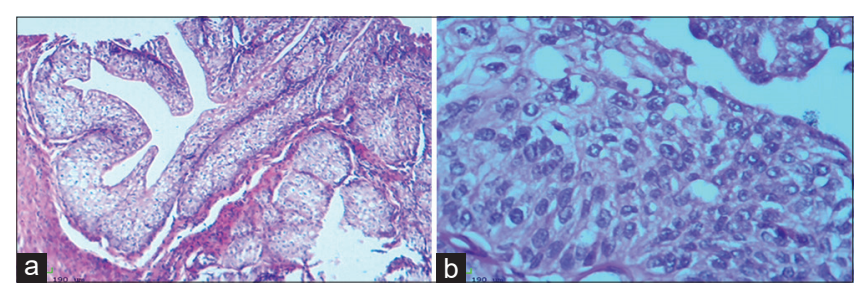

Figure 1: Tissue section of urinary bladder showing high grade transitional cell carcinoma in a 62 years old male patient. a, (H\&E Stain $\times 10) b$, $($ H\&E Stain $\times 40)$. biological potential of the tumors which may help in better prediction of their clinical outcome. Different studies have revealed that alteration in cell cycle regulation is a major key event in determining the biological behavior of bladder carcinoma [24]. The P53 gene is a tumor suppressor gene playing an essential role in regulation of the cell cycle. So that, when DNA damage occurs, the level of P53 protein is increased leading to cell cycle arrest and repair of the damaged DNA. Mutations in the P53 gene will result in the production of abnormal protein products, allowing cells with damaged DNA to continue through the cell cycle [25]. The Rb gene (RB) mutation is responsible for the $\mathrm{Rb}$; however surviving patients are particularly prone to develop a second primary tumor, particularly osteosarcoma, small cell lung carcinoma, soft tissue sarcomas, breast carcinoma, and genitourinary carcinomas [26].

In this study, the age ranged from 28 to 87 years with mean age (60.2) years, which was not came in accordance with data from other Iraqi studies which had reported a different mean age by Batool [23] with mean age (56.8) years, while the study of Mazin [27] was corresponding to this study with mean age (60) years. In this study, the percentage of male to female
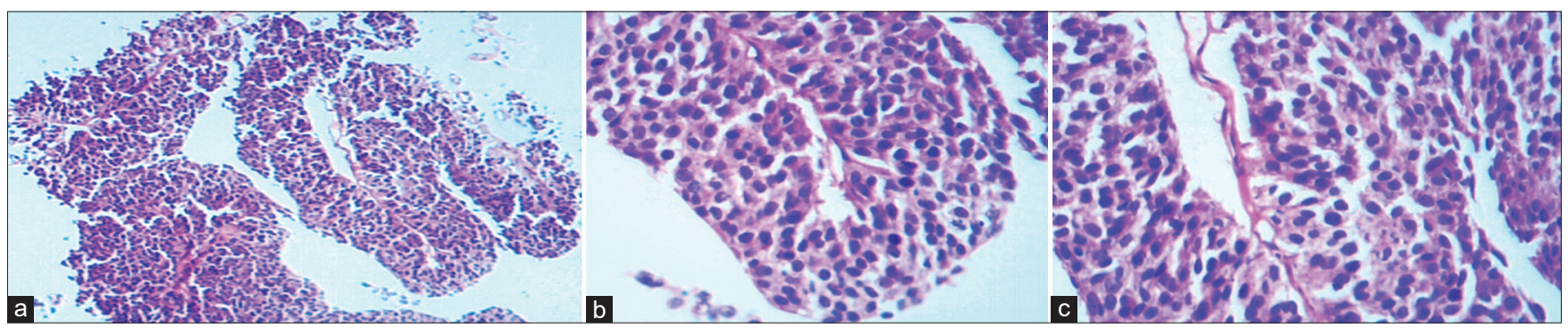

Figure 2: Tissue section of urinary bladder in a 67-year-old patient showing low grade transitional cell carcinoma. $a,(\times 4) b,(\times 10) c,(\times 40)$
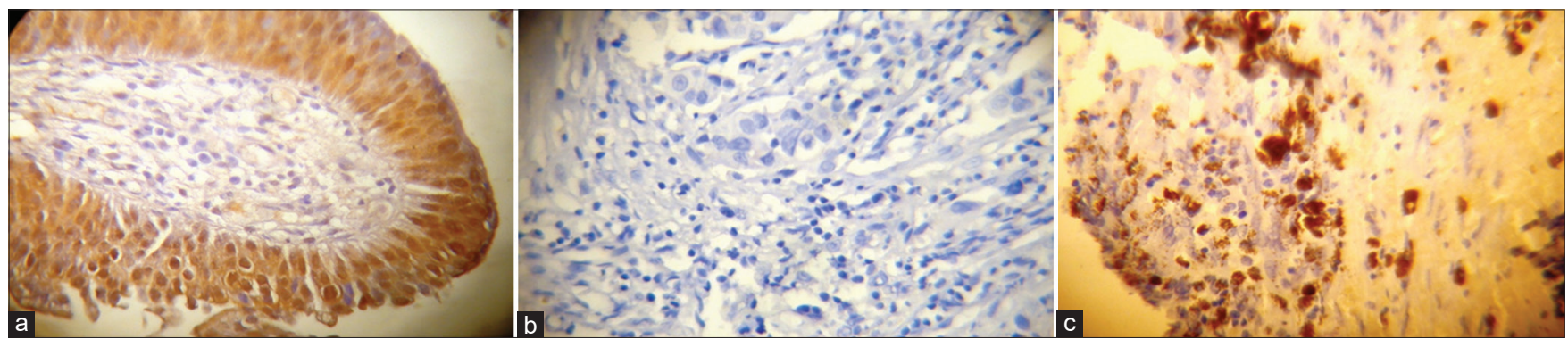

Figure 3: $p$ Rb immunohistochemistry staining. a. Tissue section of urinary bladder with TCC showing nuclear staining (arrow) (Rb IHC Stain $\times 40$ ). $b$. Negative control ( $R b I H C$ Stain without the primary antibody $\times 40)$. c. Positive control (small cell carcinoma of the lung)(arrow) $(R b$ IHC Stain $\times 40$ )
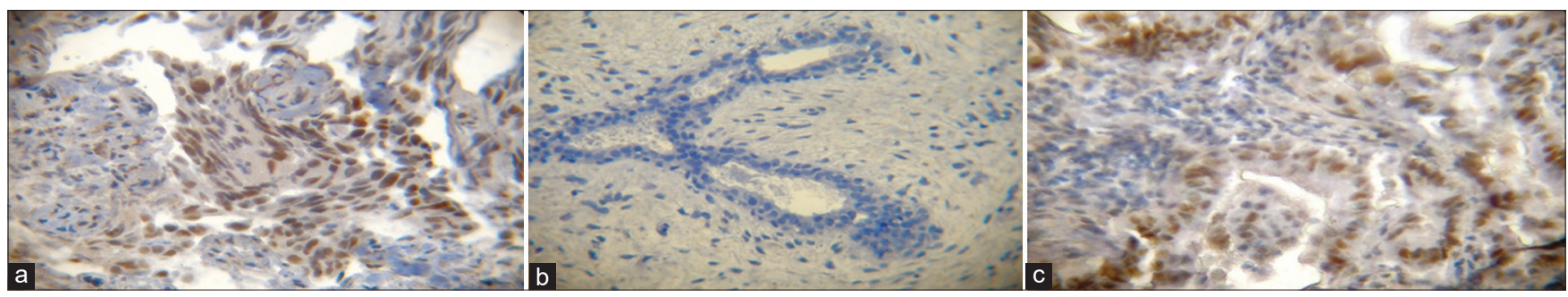

Figure 4: p53 immunohistochemical staining. a. Tissue section showing transitional cell carcinoma of the urinary bladder showing positive nuclear staining (arrow) (P53 IHC Stain $\times 40$ ). b. Positive control (adenocarcinoma) (P53 IHC Stain ×40). c. Negative control by omitting the primary antibody from the same TCC tissue (P53 IHC Stain without the primary antibody $\times 40)$ 
distribution was (2.2:1), which is rather less than the ratio mentioned by Velthoven et al. [28]. It is comparable to other studies in our country like these recorded by Mazin [27] and Batool [23] (2.75/1, and 2.69/1 respectively) and to Neal et al. study that showed incidence rates of $144.0 / 100,000$ person-years in men and 34.5/100,000 person-years in women [29]. The male preponderance is related to social, cultural and religious consideration of female patients in addition to that female confined more to house activities, while male is the main field worker. According to Neal et al., cigarette smoking is a strong risk factor for bladder carcinoma in both males and females. Compared to never-smokers $(69.8 / 100,000$ person-years in males and $16.1 / 100,000$ person-years in females), $x$ smokers and current smokers have an increased risk of BLCA in both males (x smokers, 154.6/100,000 person-years and current smokers, 276.4/100,000 person-years) and females (x smokers, 40.7/100,000 person-years; and current smokers, 73.6/100,000 person-years) [29]. In this study, the percentage of smokers was more than non-smokers (59.4 vs. $40.6 \%$ ), while it was ( $70 \%$ vs. $30 \%)$ as recorded by Mazin [27] and (68.7\% vs. $31.2 \%)$ as recorded by Batool [23]. Chronic bacterial infection with urinary calculus and obstruction may predispose to development of BLCA. Squamous cell carcinoma is the most common entity in these cases. Compared to nonsquamous carcinoma, schistosomiasis is more commonly associated with squamous cell carcinoma [30]. In this study (14) (43.8\%) out of 32 patients with TCC had UTI with $55.5 \%$ of the high grade tumors have history of UTI. The positive relationship between history of recurrent lower UIT was showed in a study of Vermeulen et al. that revealed regular lower UTI is associated with increased risk of urinary BLCA (men: 6.6 [4.2-11]; women: 2.7 [2.0-3.5]), with much stronger effects in muscle-invasive cancers [31]. In this study, (5) (15.6\%) out of 32 patients with TCC had renal stones and this is less what had been recorded in other study done in Brazil by TobiasMachado et al. [32] (33\%) of the patients had renal stones, this difference might due to different time and place. In the epidemiologic studies, positive family history carries a two-fold increase in the BLCA risk, however; it is uncertain whether this is due to a genetic and/or the shared environmental factors for familial aggregation [33]. A new study demonstrated that hereditary non-polyposis colorectal cancer was associated with an increased risk of BLCA. Since 2008, genome-wide association study (GWAS) had been used to identify the susceptibility loci for bladder carcinoma [34]. In this study, (3) (9.4\%) out of 32 patients had positive family history for TCC. In this study, (17) $(53.1 \%)$ out of the 32 patients with TCC presented with recurrent tumor and this came in accordance with another much larger study done by Hall et al. [35] in Dallas USA which shows (51\%) out of 252 patients with TCC had recurrence. However, this was almost the double the percentage shown by study done in our country by Al-Abbasi [36] who shows that $29.63 \%$ out of 54 patients with TCC had recurrent tumor. These differences could be explained the selection criteria and sample size. In this study, 14 (43.8\%) out of 32 patients were with low grade TCC while $18(56.2 \%)$ were with high grade TCC which disagree with other study done by Kadhim et al. [37] there sample where include in the region of Middle East (Jordan, Syria and Iraq) who found that $66 \%$ of cases where with high grade tumor versus $33 \%$ where of low grade tumor. Probably, different environmental and ethnic factors operate in these three countries. In this study (24) (75\%) out of 32 patients with TCC was in T1 category of tumor size and stage and this was much less as recorded by study done by Al-Abbassi [36] who shows (18.51\%) patients out of 54 patients with TCC which lie in this category but in other study done in USA by Cheng et al. [38] who shows that $(52 \%)$ out of 105 patients with TCC lie in this category. In this study, (3.1\%) 1patient out of 32 TCC patients shows regional lymph node metastasis while it was (15.9\%) 21 patients out of 132 TCC patients in a study done by Nakanishi et al. [39] in Japan. These differences can be attributed to differences in the sample size and criteria of patient selection. In this study there was no statistical significant association between age and tumor grade since $p=0.1$, several studies support our conclusion such as Iranian study done in Sina hospital by Mohseni et al. [40] ( $p=0.59)$, also Yang et al. have concluded the same results and noted that patient's age is not a significant predictor for the prognosis [41]. Yossepowitch and Dalbagni [42] also found that there was no difference in the pathological grade distribution in young adults as compared to the older individuals. However, a study done in USA by Hall et al. showed that there was an association between tumor grade and age and the $p$ value was (0.042) [35]. Our study showed a higher incidence of both high and low grade TCC in males. There was no correlation between gender of the patients in this study and tumor grade $(p=0.288)$. However, an Iranian study conducted by Mohseni et al. [40] showed an association between gender and tumor grade $(p=0.029)$. Similarly, Batool also showed a higher incidence of high grade tumor in females. However, it came in correspondence to study done by Sunita et al. [43]. These differences are probably related to sample size and patients selection. In our study, smoking showed no correlation with the tumor grade ( $p=0.275$ ). Other studies, however, found a positive association between these two parameters for example, the study conducted by Mohseni et al. [40]. The deviation of our results from these and other studies is certainly related to the smaller sample size. There was a strong association between tumor grade and stage in our study $p=0.003$ and this is like what revealed in the study done by Hall et al. [35] $p=0.0001$ and in other study done by Cheng et al. [38] $p=0.002$ and also this shown by study done Edinburgh, UK by Stewart et al. [44] $p=0.001$. Regarding $p R b$ scores, two cases 
$(6.2 \%)$ out of the presented 32 patients with TCC with negative $\mathrm{pRb}$ intensity score and two patients with negative percentage score. The remaining 30 patients show different intensity and percentage scores. In this study, 16 patients $(50 \%)$ with low score, 11 patients $(34.4 \%)$ revealed moderate intensity, and three patients $(9.2 \%)$ revealed high intensity. While 15 patients $(46.9 \%)$ revealed +1 score, 11 patients $(34.4 \%)$ revealed +2 score, and four patients $(12.5 \%)$ revealed +3 score. While Wright et al. [45] found that Rb protein was undetectable in $(18 \%)$ out of 84 patients with TCC of the bladder, Cordon-Cardo et al. [46] scored (19\%) as negative for $\mathrm{Rb}$ expression, although their negative group also included tumor showing $<10 \%$ positive cells. Regarding the $\mathrm{P}^{53}$ scores, there was a significant overexpression of $\mathrm{P}^{53}$ among the studied 32 TCCs with a positive frequency of $82.2 \%(p<0.0001)$. Similar results have been quoted by many investigators such as Du et al. [47], and Al-Abassi [36]; their positive frequencies were $82 \%$ and $83.33 \%$, respectively, with a $(p<0.0001)$. However, other investigators cited lower frequency figures of $\mathrm{P}^{53}$ positivity such as Sarkis et al. [48], Lu et al. [49] and Sunanda et al. [24]; their quoted positive frequencies were $58 \%, 50.7 \%$, and $62 \%$, respectively. The difference between low-grade and high-grade tumors regarding $\mathrm{pRb}$ percentage score was statistically significant $(p=0.026)$, but it was not significant regarding the intensity score $(p=0.094)$. Shariat et al. [50] and Khaled [51] found that altered Rb protein expression was not associated with tumor grade $(p=0.622$ and 0.71 , respectively). In this study, there was significant correlations between tumor stage and both $p R b$ intensity and percentage scores $(p=0.044$ and 0.042 , respectively). Similar results were obtained by Shariat et al. [50] who found that altered Rb protein expression is associated with different tumor stages and the degree of tumor invasion $(p=0.003)$. Along the same lines, Khaled [51] found significant correlation between tumor stage and $\mathrm{Rb}$ protein expression $(p=0.023)$.

The difference between low grade and high grad regarding $p^{53}$ intensity score was significant $p=0.022$. In agreement with these findings, Shiina et al., [52] found that p53 is positively correlated with histological grade of tumor also Al-Abassi [36] found it correlated with $P=0.003$. The difference between low grade and high grade regarding $\mathrm{p}^{53}$ percentage score was significant $p=0.049$. In agreement with our study, many investigators reported that p53 nuclear immunostaining was associated with the grade of BLCA. Cheng et al., [53] showing that p53 immunostaining was positive in $26 \%$ of Grade I, $57 \%$ of grade II, and $42 \%$ of grade III. Findings of the current work also agreed by Kilicli-Camur et al. [54], Lu et al. [49], and Sunanda et al. [24]. Al-Abassi [36] also found it correlated with $p=0.013$. The difference between different tumor stages regarding $p^{53}$ intensity score was significant and $p=0.018$. From these readings of P53 overexpression, it looks that as the size of tumor increases, more P53 immunostaining will be noticed. In agreement with the current study by Kilicli-Camur et al., [54], while Cheng et al. [53] reported that p53 immunostaining was positive in $23 \%$ Of Ta-T1, $15 \%$ of $\mathrm{T} 2-3$, and $15 \%$ of $\mathrm{T} 4$. The difference between different tumor stages regarding $\mathrm{p}^{53}$ percentage score was significant $\mathrm{p}=0.019$. In agreement with these findings were reported by Al-Abassi [36] with $p=0.014$. Also this reported by Lu et al., [50], and Kilicli-Camur et al., [54]. In the current work and in comparison between stage Ta and stage T3 andT4, a significant difference was found $(p<0.05)$. This finding is in agreement with studies reported by Kilicli-Camur et al. [54] and Liuxi et al. [55] who found that p53 mutation with low expression of PCDH17 was significantly associated with MIBC. P53 was found to be more frequently expressed in those with advanced stage that explains the aggressive biological behavior of tumor, which is well known to be correlated with the degree of differentiation.

\section{Conclusions}

Tumor's grade was found to be correlated with the tumor stage but not with the patient's age, gender, family history of TCC, smoking habits, history of urinary tract infections nor lithiasis, nor the recurrence of the tumor. The $\mathrm{pRb}$ intensity and the percentage scores were correlated to each other and to tumor's grade and stage, except for the pRb intensity which showed no correlation with the tumor's grade. The P53 intensity and percentage scores were correlated to each other and also to tumor's grade and stage, so that P53 is over expressed in tumors with higher grade and stage.

\section{References}

1. Jemal A, Murray T, Ward E, Samuels A, Tiwari RC, Ghafoor A et al. Cancer statistics, 2005. CA Cancer J Clin. 2005;55(1):1030. https://doi.org/10.3322/canjclin.55.1.10 PMid:15661684

2. Reddy PV. Prognostic value of P53 nuclear overexpression in bladder cancer. Int J Med Res Rev. 2017;5(6):569-70.

3. Crow $P$, Ritchie AW. National and international variation in the registration of bladder cancer. BJU Int. 2003;92(6):563-6. https://doi.org/10.1046/j.1464-410x.2003.04421.x PMid:14511034

4. Pernick N. p53. Available from: https://www.pathologyoutlines. com/topic/stainsp53.html. [Last accessed on 2021 Mar 13].

5. Goussia AC, Alexandra PB, Antonia C, Panagiotis K, Panagiotis K, John KE, et al. Alterations of p53 and Rb pathways are associated with high proliferation in bladder urothelial carcinomas. Anticancer Res. 2018;38(7):3985-88. https://doi. org/10.21873/anticanres.12685

PMid:29970521 
6. Malumbres M, Barbacid M. To cycle or not to cycle: A critical decision in cancer. Nat Rev Cancer. 2001;1(3):222-31. https:// doi.org/10.1038/35106065

\section{PMid:11902577}

7. Marr BP, Hung C, Gobin YP, Dunkel IJ, Brodie SE, Abramson DH Success of intra-arterial chemotherapy (chemosurgery) for retinoblastoma: Effect of orbitovascular anatomy. Arch Ophthalmol. 2012;130(2):180-5. https://doi.org/10.1001/ archophthalmol.2011.386

PMid:22332209

8. Ghassemi F, Shields CL. Intravitreal melphalan for refractory or recurrent vitreous seeding from retinoblastoma. Arch Ophthalmol. 2012;130(10):1268-71. https://doi.org/10.1001/ archophthalmol.2012.1983

PMid:23044940

9. Munier FL, Gaillard MC, Balmer A, Soliman S, Podilsky G, Moulin AP, et al. Intravitreal chemotherapy for vitreous disease in retinoblastoma revisited: From prohibition to conditional indications. Br J Ophthalmol. 2012;96(8):1078-83. https://doi. org/10.1136/bjophthalmol-2011-301450 PMid:22694968

10. Liukkonen $\mathrm{T}$, Lipponen $\mathrm{P}$, Raitanen $\mathrm{M}$, Kaasiner $\mathrm{E}$, AlaOpas M, Rajala P, et al. Evaluation of p21WAF1/CIP1 and cyclin D1 expression in the progression of superficial bladder cancer. Urol Res. 2000;28(5):285-92. https://doi.org/10.1007/ s002400000116

PMid:11127704

11. Sgambato A, Migaldi M, Faraglia B, De Aloysio G, Ferrari P, Ardito $\mathrm{R}$, et al. Cyclin $\mathrm{D} 1$ expression in papillary superficial bladder cancer: Its association with other cell-cycle associated proteins, cell proliferation and clinical outcome. Int $\mathrm{J}$ Cancer. 2002;97(5):671-78. https://doi.org/10.1002/ijc.10055 PMid:11807796

12. Tsai TS, Tsai YS, Chow NH. The prevalence and clinicopathologic correlate of p16INK4a, retinoblastoma and p53 immunoreactivity in locally advanced urinary bladder cancer. Urol Oncol. 2004;22(2):112-8. https://doi.org/10.1016/ s1078-1439(03)00176-5

PMid: 15082007

13. Burger M, Catto JW, Dalbagni G, Grossman HB, Herr H, Karakiewicz $\mathrm{P}$, et al. Epidemiology and risk factors of urothelial bladder cancer. Eur Urol. 2013;63(2):234-41. https://doi. org/10.1016/j.eururo.2012.07.033

PMid:22877502

14. Mak RH, Hunt D, Shipley WU, Efstathiou JA, Tester WJ, Hagan MP, et al. Long-term outcomes in patients with muscleinvasive bladder cancer after selective bladder-preserving combined-modality therapy: A pooled analysis of radiation therapy oncology group protocols 8802, 8903, 9506, 9706, 9906, and 0233. J Clin Oncol. 2014;32(34):3801-9. https://doi. org/10.1200/jco.2014.57.5548

PMid:25366678

15. Woldu SL, Bagrodia A, Lotan Y. Guideline of guidelines: Nonmuscle-invasive bladder cancer. BJU Int. 2017;119(3):371-80 https://doi.org/10.1111/bju.13760 PMid:28058776

16. Amin MB, Smith SC, Reuter VE, Epstein JI, Grignon DJ, Hansel DE, et al. Guideline of guidelines: Non-muscle-invasive bladder cancer. BJU Int. 2015;28:612-30.

17. Mitra AP. Molecular substratification of bladder cancer: Moving towards individualized patient management. Ther Adv Urol. 2016;8(3):215-33.

PMid:27247631

18. Frantzi M, Latosinska A, Fluhe L, Hupe MC, Critselis E, Kramer MW, et al. Developing proteomic biomarkers for bladder cancer: Towards clinical application. Nat Rev Urol. 2015;12(6):317-30. https://doi.org/10.1038/nrurol.2015.100 PMid:26032553

19. Blancato J, Singh B, Liu A, Liao DJ, Dickson RB. Correlation of amplification and overexpression of the c-myc oncogene in high grade breast cancer: $\mathrm{FISH}$, in situ hybridization and immunohistochemical analysis. Br J Cancer. 2004;90(8):161219. https://doi.org/10.1038/sj.bjc.6601703 PMid:15083194

20. Apple SK, Hecht JR, David W. Immunohistochemical evaluation of K-ras, P53, and HER-2/neu expression in hyperplastic, dysplastic, and carcinomatous lesions of the pancreas: Evidence for multistep carcinogenesis. Hum Pathol. 1999;30(2):123-30. https://doi.org/10.1016/s0046-8177(99)90265-4 PMid: 10029438

21. Iraqi Cancer Registry 2012/Ministry of health/Iraq. Available from: https://www.bccru.uobaghdad.edu.iq. [Last accessed on 2021 Mar 14].

22. Daniel L. TNM staging: The common language for cancer care. Am Joint Committee Cancer. 2008.

23. Batool JJ. Al-heety: Immunohistochemical expression of caspase- 3 and $\mathrm{Bcl}-2$ in urinary bladder carcinoma. J Urol. 2010;4(5):42-74.

24. Chatterjee SJ, Datar R, Youssefzadeh D, George B, Goebell PJ, Stein JP, et al. Combined effects of p53, p21, and $\mathrm{pRb}$ expression in the progression of bladder transitional cell carcinoma. J Clin Oncol. 2004;22(6):1007-13. https://doi. org/10.1200/jco.2004.05.174

PMid: 14981105

25. Lichtenstein AV, Potapova GI. Genetic defects as tumor markers. J Mol Biol. 2003;37(2):159-69.

26. Favoni RE, De Cupis A. The role of polypeptide growth factors in human carcinomas: New targets for a novel pharmacological approach. Natl Cancer Inst. 2000;52(2):179-206.

PMid:10835099

27. Mazin J. Clinicopathological study of urinary bladder carcinoma by detection of the molecular marker $\mathrm{p} 53$ by in situ hybridization, before and after treatment. 2009;4:63-74.

28. Velthoven RV, Petein M, Osterlink W, Kiss R, Decaestecker C Identification by quantitative chromatin pattern analysis of patients at risk for recurrence of superficial tranitional bladder carcinoma. J Urol. 2000;164(6):2134-37. https://doi. org/10.1016/s0022-5347(05)66984-4 PMid:11061942

29. Freedman ND, Silverman DT, Hollenbeck AR, Schatzkin A, Abnet CC. Association between smoking and risk of bladder cancer among men and women. JAMA. 2011;306(7):737-45. https://doi.org/10.1001/jama.2011.1142

PMid:21846855

30. Rambau PF, Chalya PL, Jackson K. Schistosomiasis and urinary bladder cancer in North Western Tanzania: A retrospective review of 185 patients. Infect Agent Cancer. 2013;8(1):19. https://doi.org/10.1186/1750-9378-8-19 PMid:23705833

31. Vermeulen SH, Hanum N, Grotenhuis AJ, Castaño-Vinyals G, van der Heijden AG, Aben KK, et al. Recurrent urinary tract infection and risk of bladder cancer in the Nijmegen bladder cancer study. Br J Cancer. 2015;112(3):594-600. https://doi. org/10.1038/bjc.2014.601

PMid:25429525

32. Machado MT, Pinto MA, Juliano RV, Mattos MH, Wroclawski ER. Alternatives for distal ureter resection in laparoscopic nephroureterectomy. Braz J Urol. 2002;28(2):109-15.

33. Mueller CM, Caporaso N, Greene MH. Familial and genetic risk of transitional cell carcinoma of the urinary tract. 
Urol Oncol. 2008;26(5):451-64. https://doi.org/10.1016/j. urolonc.2008.02.016

34. Chu H, Wang M, Zhang Z. Bladder cancer epidemiology and genetic susceptibility. J Biomed Res. 2013 May; 27(3):170-8. PMid:18562223

35. Hall MC, Womack S, Sagalowsky AI, Carmody T, Erickstad MD, Roehrborn CG. Prognostic factors, recurrence, and survival in transitional cell carcinoma of the upper urinary tract: A 30-year experience in 252 patients. Urology. 1998;52(4):594-601. https://doi.org/10.1016/s0090-4295(98)00295-7 PMid:9763077

36. Al-Abassi D. IHC study of TCC of urinary bladder by application of VEGF in correlation to P53. BMC Res Notes. 2008;3:31-54.

37. Kadhim HS, Abdulamir AS, Hafidh RR, Abubaker F, Abbas KA. Investigations in the molecular events of transitional cell carcinoma of the bladder. Am J Biochem Biotechnol. 2008;4(4):408-15. https://doi.org/10.3844/ajbbsp.2008.408.415

38. Cheng L, Neumann RM, Weaver AL, Cheville JC, Leibovich BC, Ramnani DM, Scherer BG, et al. Grading and staging of bladder carcinoma in transurethral resection specimens. Am J Clin Pathol. 2000;113(2):275-79. https://doi. org/10.1309/94b6-8vfb-mn9j-1nf5

PMid: 10664630

39. Nakanishi K, Kawai T, Aida S, Kasamatsu H, Aurues T, Ikeda T. Expression of $\mathrm{p} 27^{\mathrm{Kip} 1}$ protein in transitional cell carcinoma of the upper urinary tract. Mod Pathol. 2001;14(5):371-76. PMid:11353044

40. Mohseni MG, Nourbakhsh A, Hatami ZN. Association of smoking with high-grade transitional cell carcinoma of the urinary bladder. Arch Iranian Med. 2005;8(4):286-9. https://doi. org/10.1038/modpathol.3880320

41. Yang $\mathrm{MH}$, Yen CC, Chen PM, Wang WS, Chang $\mathrm{YH}$, Huang WJ, et al. Prognostic factors-based risk-stratification model for invasive urothelial carcinoma of the urinary bladder in Taiwan. Urology. 2002;59(2):232-38. https://doi.org/10.1016/ s0090-4295(01)01590-4

PMid:11834392

42. Yossepowitch O, Dalbagni G. Transitional cell carcinoma of the bladder in young adults: Presentation, natural history, and outcome. J Urol. 2002;168(1):61-6. https://doi.org/10.1016/ s0022-5347(05)64832-x PMid:12050493

43. Saxena S, Burra U, Varma S, Aggarwal A. Tripathi MJ. Role of in vitro Cytotoxicity Assessment and Immunologic Enhancement in the Management of Superficial Bladder Cancer. 2004;p20-22.

44. Stewart GD, Bariol SV, Grigor KM, Tolley DA, Mcneill SA. A comparison of the pathology of transitional cell carcinoma of the bladder and upper urinary tract. J Urol Int. 2005;95(6):79193. https://doi.org/10.1111/j.1464-410x.2005.05402.x PMid:15794784

45. Wright $\mathrm{C}$, Thomas $\mathrm{D}$, Mellon $\mathrm{K}$, Neal $\mathrm{DE}$, Horne $\mathrm{CH}$. Expression of retinoblastoma gene products and $\mathrm{p} 53$ protein in bladder carcinoma: Correlation with ki67 index. $\mathrm{Br} \mathrm{J}$ Urol.
1995;75(2):173-9. https://doi.org/10.1111/j.1464-410x.1995. tb07306.x

PMid:7850321

46. Cordon-Cardo C. Mutation of cell cycle regulators: Biological and clinical implications for human Neoplasia. Am J Pathol. 1995;147(3):545-60.

PMid:7677168

47. Du J, Chen GG, Vlantis AC, Xu H, Tsang RK, van Hasselt AC. P53 in predicting recurrence and progression of urothelial cel carcinomas of urinary bladder. Korean J Urol. 2003;44:256-61.

48. Sarkis AS, Dalbagni G, Cordon-Cardo G, Zhang ZF, Sheinfeld J, Fair WR, et al. Nuclear overexpression of p53 protein in transitional cell carcinoma of bladder: A marker for disease progression. J Natl Cancer Inst. 1993;85(1):53-9. https://doi. org/10.1093/jnci/85.1.53

PMid:7677935

49. Lu ML, Wikman F, Orntoft TF, Charytonowicz E, Rabbani Farhang, Zhang Z, et al. Impact of alterations affecting the p53 pathway in bladder cancer on clinical outcome. Clin Cancer Res. 2002;8(1):171-9.

PMid: 11801555

50. Shariat SF, Takunaga H, Zhou JH, Kim JH, Ayala GE, Benedict WF, et al. P53, p21, pRB, and p16 Expression predict clinical outcome in cystectomy with bladder cancer. J Clin Oncol. 2004;22(6):1014-24. https://doi.org/10.1200/jco.2004.03.118

PMid:14981102

51. Khaled HM, Bahnassy AA, Raafat AA, Zekri AN, Madboul MS Mokhtar NM. Clinical significance of altered nm23-H1, EGFR, RB and p53 expression in bilharzial bladder cancer. BMC Cancer. 2009;9:32. https://doi.org/10.1186/1471-2407-9-32 PMid: 19171060

52. Shiina $H$, Igawa $M$, Shigeno $K$. Clinical significance of $m d m 2$ and p53 expression in bladder cancer. A comparison with cell proliferation and apoptosis. Oncology. 1999;56(3):239-47. https://doi.org/10.1159/000011971

PMid: 10202280

53. Cheng HL, Trink B, Tzai TS, Liu HS, Chan SH, Ho CL, et al. Overexpression of c-met as a prognostic indicator for transitional cell carcinoma of the urinary bladder: A comparison with p53 nuclear accumulation. J Clin Oncol. 2002;20(6):1544-50. https:// doi.org/10.1200/jco.2002.20.6.1544

PMid:11896103

54. Camur NK, Kilicaslan I, Gulluoglu MG, Esen T, Uysal V. Impact of $\mathrm{p} 53$ and $\mathrm{Ki}-67$ in predicting recurrence and progression of superficial ( $\mathrm{pTa}$ and $\mathrm{pT} 1$ ) urothelial cell carcinomas of urinary bladder. Pathol Int. 2002;52(7):463-69. https://doi. org/10.1046/j.1440-1827.2002.01371.x PMid: 12167105

55. Liuxi C, Ying L, Qi Z, Mingming Z, Xuemeng $\mathrm{H}$, Qiujie L, et al. p53/PCDH17/Beclin-1 proteins as prognostic predictors for urinary bladder cancer. J Cancer. 2019;10(25):6207-16.

PMid:31772653 